\title{
Editorial
}

Our sixth issue manifests our previously stated aims to seek contributions from those working in the country's museum, art gallery and library sectors as well as publishing research by new researchers. We also trust it evidences two other key goals of the editorial team: to place considerable importance on the use of photographs and illustrations in the journal and to provide space for commentary and personal recollection by those interested in our art, design and media history. Our profile commentary in this issue pays tribute to and features the photography of Peter Peryer who died in September last year. Sian Van Dyk, a curator at the Dowse Art Museum, reflects on Peryer's ability as a photographer to "tap into an underlying New Zealand psyche with elegance". She states that Peryer's image making mingled "the uncanny and the beautiful to invoke our curiosity in objects and scenes we may otherwise pass by without a second glance". Susannah Whaley looks at a body of work by artist Rita Angus from the late 1930 s to the 1950 s where she sought to look beyond "New Zealand gender normalities" to craft an image Angus called the "New Madonna'. Whaley argues the portraits and self-images that the artist worked on during this period "highlight female independence, while concomitantly acknowledging female sexuality". She further contends that Angus's art becomes "a medium to validate who she is as a woman and an artist".

As a hobbyist photographer and historian Russell Duncan extensively photographed sites associated with early European explorers in New Zealand. His aim, says Auckland curator Emma Jameson, was to record where these explorers, in particular Captain James Cook, left their mark and how the passage of time might have altered the landscape. The article illustrates how Duncan's photographic practice draws attention to a photograph's inherent tension, depicting what Barthes identifies as the here-now and the there-then. The photographed object or scene remains 'alive' in the traces of the moment depicted in the photograph whilst simultaneously the image also suggests it is of a time past or 'dead'.
Whilst Duncan's photography was interested in connections to the period of colonial exploration and was purblind to indigenous presence; Laura Campbell looks at early movements in New Zealand which while acknowledging our European cultural traditions sought also to explore the relationships between Maori and Pakeha art. She notes that at the end of nineteenth century and the beginning of the twentieth century there was "a new found desire to integrate Maori and Pacific art into both public and private aesthetic spaces". By acknowledging the beauty of Maori and Pacific art and adding this appreciation to the European art traditions, "this ultimately translated into something original and specific to New Zealand".

Herbs, a group of Maori and Pacific Island musicians, introduced a distinctive form of 'Pacific reggae' to New Zealand. Elizabeth Turner focuses on the cover of their $1981 \mathrm{EP}$ record What's Be Happen? to discuss their significant cultural and political influence in an important period of activism in this country. The cover is a photographic image of the final day of the Bastion Point occupation in Orakei, Auckland on 25 May, 1978. Turner identifies the choice of cover image and other visual elements as "a cultural and political statement of identity".

If we were looking for a theme for this issue we might highlight the power of visual imagery. However, there has been no attempt here to dress Issue 6 in any thematic cloak. Our intention in every journal is merely to feature the diversity and richness in New Zealand's art, design and media history. We trust you find this selection of articles fulfils our intent.

\section{Alan Cocker}

